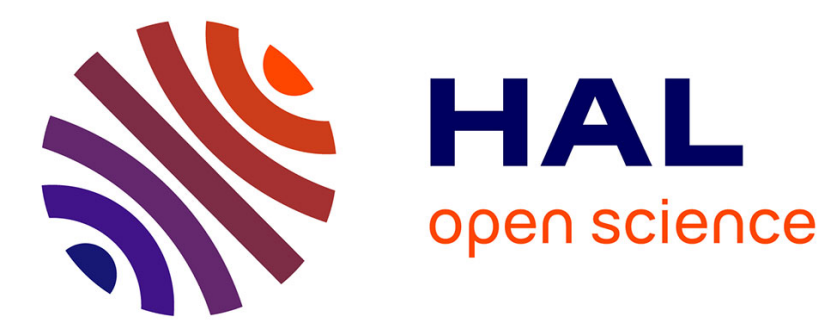

\title{
Development of Type I Gastric Carcinoid in patients with Chronic atrophic gastritis
}

Lucy Vannella, Andrea Sbrozzi-Vanni, Edith Lahner, Cesare Bordi, Emanuela

Pilozzi, Vito Domenico Corleto, John Frederick Osborn, Gianfranco Delle

Fave, Bruno None Annibale

\section{To cite this version:}

Lucy Vannella, Andrea Sbrozzi-Vanni, Edith Lahner, Cesare Bordi, Emanuela Pilozzi, et al.. Development of Type I Gastric Carcinoid in patients with Chronic atrophic gastritis. Alimentary Pharmacology and Therapeutics, 2011, 33 (12), pp.1361. 10.1111/j.1365-2036.2011.04659.x . hal-00632733

\section{HAL Id: hal-00632733 \\ https://hal.science/hal-00632733}

Submitted on 15 Oct 2011

HAL is a multi-disciplinary open access archive for the deposit and dissemination of scientific research documents, whether they are published or not. The documents may come from teaching and research institutions in France or abroad, or from public or private research centers.
L'archive ouverte pluridisciplinaire HAL, est destinée au dépôt et à la diffusion de documents scientifiques de niveau recherche, publiés ou non, émanant des établissements d'enseignement et de recherche français ou étrangers, des laboratoires publics ou privés. 


\begin{tabular}{l}
\hline Alimentary Pharmacology \\
\hline \& Therapeutics \\
\hline
\end{tabular}

\section{Development of Type I Gastric Carcinoid in patients with Chronic atrophic gastritis}

\begin{tabular}{|r|l|}
\hline Journal: & Alimentary Pharmacology \& Therapeutics \\
\hline Manuscript ID: & APT-1121-2010.R1 \\
\hline Wiley - Manuscript type: & Original Scientific Paper \\
\hline Date Submitted by the & 11 -Mar-2011 \\
\hline Complete List of Authors: & $\begin{array}{l}\text { Vannella, Lucy } \\
\text { Sbrozzi-Vanni, Andrea } \\
\text { Lahner, Edith } \\
\text { Bordi, Cesare } \\
\text { Pilozzi, Emanuela } \\
\text { Corleto, Vito } \\
\text { osborn, john; La Sapienza University of Rome, Public Health } \\
\text { Science } \\
\text { Delle Fave, Gianfranco } \\
\text { Annibale, Bruno; University, Clinical Science }\end{array}$ \\
\hline Keywords: & $\begin{array}{l}\text { Stomach and duodenum < Organ-based, Gastritis < Topics, Gastric } \\
\text { cancer < Disease-based, Endoscopy < Topics }\end{array}$ \\
\hline
\end{tabular}

\section{SCHOLARONE ${ }^{m}$ Manuscripts}


DEVELOPMENT OF TYPE I GASTRIC CARCINOID IN PATIENTS WITH CHRONIC

\section{ATROPHIC GASTRITIS}

Running Head : Type I Gastric Carcinoids in atrophic gastritis

Lucy Vannella, M.D., Andrea Sbrozzi-Vanni, M.D., Edith Lahner, M.D., Cesare Bordi*, M.D., Emanuela Pilozzi\#, M.D., Vito Domenico Corleto^ ${ }^{\wedge}$, M.D., John Osborn ${ }^{\circ}$, Gianfranco Delle Fave, M.D., Bruno Annibale, M.D.

Dipartimento Medico-chirurgico di Scienze cliniche, tecnobiomediche e medicina traslazionale, Sant'Andrea Hospital, School of Medicine, University Sapienza of Rome, Italy; *Department of Pathology, University of Parma, Italy; \#Department of Pathology, Sant'Andrea Hospital, School of Medicine, University Sapienza of Rome, Italy; ^Centro Ricerche "Fate Bene Fratelli", San Pietro Hospital, Roma, Italy; ${ }^{\circ}$ Department of Public Health Sciences, University Sapienza of Rome, Italy.

Key Words: chronic atrophic gastritis, type I gastric carcinoid, incidence, prevalence

\section{Word Count: 3156}

\section{ADDRESS for Correspondence:}

Bruno Annibale,

Dipartimento Medico-Chirurgico di Scienze Cliniche,

Tecnobiomediche e Medicina Traslazionale,

Sant'Andrea Hospital, School of Medicine, University Sapienza of Rome, Italy

Via di Grottarossa 1035, 00189 Rome (Italy)

Fax number +39064455292 e-mail: bruno.annibale@uniroma1.it 


\begin{abstract}
Background: Long-term observational studies assessing the incidence of Type I Gastric Carcinoid (GC) in patients with chronic atrophic gastritis are few. The aim of the present study was to evaluate the occurrence at diagnosis and during follow-up and to identify patient features associated with the presence of TypeIGC in a cohort of chronic atrophic gastritis patients.

Methods: 367 chronic atrophic gastritis patients (245 females, age 54[18-79]years) underwent regular follow-up by gastroscopy. The incidence of TypeIGC was determined in chronic atrophic gastritis patients with at least 2 years of follow-up $(n=214)$. Baseline clinical and histological features were analysed as factors associated with the presence of TypeIGC by univariate analysis.

Results: TypeIGC was diagnosed in $9(2.4 \%)$ patients at the moment when chronic atrophic gastritis was diagnosed. After 1463 person-years, 6 patients developed TypeIGC with an annual incidence rate (person-year) of $0.4 \%$. Patients with TypeIGC had significantly higher levels of gastrin, chromogranin A and more frequently the presence of body polyps and ECL-dysplasia compared with chronic atrophic gastritis patients without TypeIGC.

Conclusion: This cohort study shows that TypeIGC is a rare complication in patients with chronic atrophic gastritis and the presence of body polyps and ECL-dysplasia at gastroscopic/histologic evaluation are strongly associated with the presence of TypeIGC.
\end{abstract}




\section{INTRODUCTION}

Gastric carcinoids (GC) or gastric neuroendocrine tumors are tumors derived from enteterochromaffin-like (ECL) cells which are localized in the gastric fundus and corpus. The main role of ECL-cells is the secretion of histamine that, in turn, stimulates acid secretion by parietal cells (1). GC were classified in three subgroups, Type I to Type III, with different pathogenic causes and outcomes (2-4). Type I lesions are more frequent, up to $80 \%$ of the total, and are gastrin-dependent tumors which are associated with atrophic gastritis (5). Gastrin, released by G-cells in the gastric antrum, is the main factor that regulates the release of histamine and produces trophic effects upon ECL-cells (6). In chronic atrophic gastritis (CAG), the loss of appropriate glands in the body leads to achlorhydria, and consequently, hypergastrinaemia. The chronic elevation of gastrin stimulates ECL- hyperplasia and sometimes the development of Type I GC (7-8). Given that only a small group of CAG patients develop Type I GC, factors other than gastrin are necessary for the progression of ECL-cells to Type I GC.

Recently, several large studies in different countries have reported an increasing incidence of all gastric neuroendocrine tumors $(9,10)$. Although older studies reported a prevalence rate of Type I GC between 1 to $12.5 \%$ in patients with CAG (11-13), an estimate of Type I GC incidence in patients with this specific condition is unknown. In fact, long-term observational studies assessing the incidence of Type I GC in CAG patients are few (13-15). For this reason, the aim of the present study was to evaluate the occurrence of Type I GC at diagnosis and during follow-up and to identify patient features associated with the presence of Type I GC in a cohort of CAG patients. 


\section{METHODS}

\section{Patients and Study Design}

Between 1992 and 2008, we diagnosed the presence of CAG in 367 (245 females, median age 54 years, range 18-79 years) patients referred to our Unit for unexplained anaemia or long-standing dyspepsia, as described in detail elsewhere (16). Patients underwent gastroscopy with biopsies and those with proven histological diagnosis of CAG were informed about the increased risk of gastric neoplasia associated with CAG and about the need for regular follow-up by gastroscopy. Personal and clinical data, family history for gastric neoplasia and smoking habit were recorded for all patients during a clinical interview. Of the initial population, 102 patients dropped-out because 4 patients died from causes not-related to CAG and 98 patients refused to participate in further follow-up. Thus the study population included 265 patients (177 females, median age 54 years, range 20-79 years) (see Figure 1). The incidence of Type I GC was determined in CAG patients with at least 2 years of follow-up ( $\mathrm{n}=214$; median follow-up 6.3 [2-17]years), after the exclusion of prevalent Type I GC, because this interval of time was considered sufficient for the development of a new lesion of Type I GC. Regarding demographic (gender and age) and clinical features (severity of atrophy), there were no significant differences between patients of the initial CAG group ( $n=367)$, of the baseline population $(n=265)$ and of follow-up population.

Diagnosis of CAG was based on the presence of fasting gastrin above upper normal values and the histological confirmation of gastric body (corpus and fundus) atrophy based on three biopsies taken from the gastric antrum (within $3 \mathrm{~cm}$ of the pyloric ring, lesser and greater curve, anterior or posterior wall) and three biopsies from the body along the greater curve (16-17). The degree of gastritis was assessed according to the updated Sydney System (18). Atrophy of the gastric body mucosa was defined as focal or complete replacement of oxyntic glands by metaplastic pyloric or intestinal glands. Atrophy of the antral mucosa was defined as focal or 
complete disappearance of antral glands or their replacement by intestinal metaplastic epithelium (16).

The ECL-cell status was assessed according to the Solcia classification (19). Hyperplasia was defined by ECL cells proliferation $<150 \mu \mathrm{m}$ and classified as: normal pattern, simple, linear, micronodular and adenomatoid. The diagnosis of dysplasia was based on ECL proliferation between 150 and $500 \mu \mathrm{m}$, while that of carcinoid on ECL proliferation $>500 \mu \mathrm{m}$. MEN-I diagnosis was excluded (20-21). In case of a visible lesion, additional biopsies were obtained.

All biopsies were examined independently by two experienced pathologists (CB, EP), unaware of the clinical data of the patients. In the event of disagreement, the biopsies were re-examined simultaneously by both pathologists until agreement was reached (16).

Pernicious anaemia was defined as low hemoglobin concentration, MCV>100 fl together with low B12 vitamin levels, responding to intramuscular B12 vitamin treatment (22). Iron deficiency anaemia was defined as low hemoglobin concentration, $\mathrm{MCV}<80 \mathrm{fl}$ and ferritin $<30$ $\mathrm{ng} / \mathrm{ml}$ (22). The diagnosis of autoimmune thyroid disease (AITD) was based on the presence of thyroid autoantibodies and thyroiditis signs at ultrasound evaluation irrespective of thyroid function as previously described (23).

Plasma gastrin levels were determined by radioimmunoassay using antiserum 4562, kindly supplied by Prof. J.F. Rehfeld, Copenhagen, Denmark, as previously described (gastrin normal values $\leq 40 \mathrm{pg} / \mathrm{ml}$ ) (13). Chromogranin A (CgA) levels was assessed by ELISA kit (Dako A/S, Glostrup, Denmark) (CgA normal values $\leq 98 \mathrm{ng} / \mathrm{ml}$ ); Pepsinogen I was measured using a commercial RIA kit (Pepsik; Sorin, Saluggia, Italy; normal values 20-80 ng/ml); Parietal cell antibodies (PCA) were measured by immunofluorescence and $H$ pylori $\mathrm{IgG}$ antibodies using an ELISA commercial kit (GAP test IgG, Biorad, Milan, Italy) (16). H pylori infection was considered positive when the bacterium (Giemsa stain) was detected at histology and/or on the basis of a positive IgG titre for $H$ pylori (17). Bismuth-based triple regimen eradication therapy was prescribed in the case of $H$ pylori positivity and, after 6 months, the absence of $H$ pylori at 
histology and a decrease by at least $50 \%$ in the initial titre of $H$ pylori $\operatorname{IgG}$ was the criterion for the successful cure of infection (17).

\section{Follow-up Protocol}

The first follow-up gastroscopy was scheduled at intervals between 2 and 4 years after diagnosis of CAG and the same baseline bioptic sampling was repeated (24).

If Type I GC was detected, an extensive bioptic sampling of at least ten biopsies (2 biopsies in antrum, 4 in gastric body and 4 in the fundus) of the gastric mucosa was taken after 6 and 12 months (13). If Type I GC was not confirmed at two following gastroscopies, patients were followed by the general follow-up protocol. Polypoid lesions up to $5 \mathrm{~mm}$ were removed by forceps, otherwise an electrocautery snare was used. All patients with a diagnosis of Type I GC underwent at least one imaging procedure for the tumor staging (Octreoscan, CT-scan, Magnetic Resonance Imaging).

\section{Data Analysis and Statistical Evaluation}

Type I GC at diagnosis and during follow-up in CAG patients was evaluated and prevalence and incidence rates (person-year) were calculated. Quantitative data are presented as medians and ranges or, absolute counts and percentages. Mann-Whitney and Fisher exact test were used when appropriate.

Univariate analysis was performed to identify patient features associated with the presence of Type I GC. The following baseline patient characteristics were analysed: age at CAG diagnosis, gender, presence of atrophic pangastritis defined as the concomitant presence of atrophy in the gastric antrum and body, presence of pernicious anaemia, gastrin, pepsinogen $\mathrm{I}, \mathrm{CgA}$, presence of PCA, presence of dyspepsia, presence of gastric polyp, presence of ECL-dysplasia, smoking habits, presence of H.pylori, family history for gastric cancer and presence of AITD. A p value of less than 0.05 was considered statistically significant. 


\section{RESULTS \\ Occurrence of Type I GC}

Type I GC were diagnosed in 9 out of $367(2.4 \%)$ patients at the moment of the initial diagnosis of CAG (6 female, median age 59 [range 40-72] years). As shown in Table 1, all Type I GC patients but one presented polyps of the body with a diameter between 0.3 and $3 \mathrm{~cm}$ at gastroscopy. In 6 out of $9(66.7 \%)$ patients with Type I GC, the body gastric mucosa presented a severe atrophy, in the remaining cases the atrophy was moderate. The alterations of ECL-pattern associated with Type I GC were micronodular hyperplasia $(n=4 ; 44.5 \%)$ and dysplasia $(n=5$; $55.5 \%$ ). Further details of CAG patients with Type I GC such as the presence of pernicious anemia, the levels of gastrin and $\mathrm{CgA}$, the degree of body atrophy are summarized in the Table1.

Of the initial population, after the exclusion of 102 patients who dropped-out, 265 patients remained in the study and of these, 214 patients had at least 2-years follow-up (see Figure1). After 1463 person-years, 6 patients developed Type I GC with an annual incidence rate (personyear) of $0.4 \%$ (3 female, median age 57 [range 23-69] years) (Table 1). Two out of 6 patients with incident Type I GC presented ECL dysplastic lesions at first diagnosis of CAG. Observed ECL-pattern alterations associated with Type I GC were linear $(n=1 ; 16.7 \%)$, micronodular $(n=2 ; 33.3 \%)$, adenomatoid $(n=1 ; 16.7 \%)$ hyperplasia and dysplasia $(n=2 ; 33.3 \%)$.

\section{$\underline{\text { Patient Features associated with Type I GC }}$}

To identify patient features associated with the presence of Type I GC, we compared baseline clinical, biochemical and histological characteristics between CAG patients without $(n=199)$ and with Type I GC $(n=15)$. As shown in Table 2, patients with Type I GC presented significantly higher levels of gastrin and $\mathrm{CgA}$ with respect to the other group. At the moment of the diagnosis of Type I GC, 7 out of 15 Type I GC patients (46.6\%) had a diagnosis of ECL-dysplasia with 
respect to none of the other group $(\mathrm{p}<0.000001)$. Other analyzed features were similar between the two groups.

Regarding the features of gastric polyps, the gastric location, the numbers and the endoscopic appearance (sessile or pedunculated) of the polyps were not significantly different between CAG patients with and without Type I GC (see Table 3). Body polyps were more frequently found in patients with Type I GC with respect to the other group $(\mathrm{p}=0.000001)$. Twelve out of $15(80 \%)$ polyps diagnosed in CAG patients without Type I GC were hyperplastic while the remaining were adenomas $(3 / 15,20 \%)$.

\section{Management and Follow-up of Type I GC}

All polypoid lesions up to $12 \mathrm{~mm}$ underwent endoscopic polypectomy. Endoscopic polypectomy failed on the polyp of $3 \mathrm{~cm}$ because of its hard consistency. The patient, a man aged 55, underwent total gastrectomy. At histological evaluation, the tumor extended from the mucosa to the submucosa and infiltrated the muscolaris propria. Immunohistochemistry showed positivity for CgA and VMAT-2 with Ki67 proliferation index lower of 1\%. In three out of 19 local lymph nodes removed during the surgery a metastatic endocrine tumor was found. When Type I GC was diagnosed, CT-scan and Octreoscan were performed and resulted negative.

In 6 out of $15(40 \%)$ patients with Type I GC, there was a recurrence of the tumor, but all lesions were small (up to $1 \mathrm{~cm}$ ) and underwent endoscopic polypectomy (see Table 1). At the end of the study, all the patients were alive and in good health.

\section{$\underline{\text { Concomitant GI Findings }}$}

During an overall median follow-up of 6.3 [2-17] years, three intestinal-type adenocarcinomas were diagnosed [ 2 female; median age 51 (51-77) years]. All three were located in the gastric antrum and were diagnosed 8, 5 and 1 years after diagnosis of CAG. The stage of the gastric cancer was T2N1M0 in the male patient, and T1N0M0 in the two female patients. After 
gastrectomy, two patients died, one for neoplastic disease progression and the other for complications after surgery. At the end of the study, one female patient was alive and free of neoplasia.

\section{DISCUSSION}

In the present work, we followed-up a cohort of CAG patients for 1463 person-years and found an annual incidence rate (person-year) for the Type I GC of $0.4 \%$. Recently, large studies on population-based data in different countries have reported an increasing incidence of GC among all gastric malignancies and an increase of these among all gastrointestinal carcinoid lesions (910). This increase could be partially explained by the increased diffusion of diagnostic gastroscopy (25) and correlates temporally with the increasing use of proton pump inhibitors (26). To our knowledge, few studies evaluated the real incidence of Type I GC in patients with CAG because the surveillance of CAG was not recommended (27). An old study by Kokkola et al described 8 new cases of Type I GC in 416 patient-years which corresponds to an annual incidence of 2\% (14). Sjoblom et al studied 196 patients with pernicious anemia, but gastroscopy was performed only in 70 of these patients (15). After 1397 patient-years, 2 new cases of Type I GC were reported on hospital registries among the initial group of 196 patients. This figure should correspond to an annual incidence rate of $0.1 \%$, but in this study not all patients underwent gastroscopy and the incidence rate can only be obtained indirectly. These differences in the Type I GC incidence rates could be explained by the patient selection. CAG can have a wide range of clinical presentations as already reported (28). Patients included in our series had dyspepsia, iron deficiency anemia or pernicious anemia. In particular, the latter was present in almost $50 \%$ of our patients, while previous studies included exclusively patients with pernicious anemia. In our previous study, we diagnosed 1 new case of Type I GC in a smaller sample of CAG patients $(n=96)$ for a shorter period of observation (median time of 2.5 years) which corresponds to an annual incidence of $0.4 \%$ (13). Thus, in the present study, increasing both the 
cohort of CAG patients and follow-up period (median time of 6,3 years) the annual incidence rate remained constant.

At initial diagnosis of CAG, we observed 9 cases of Type I GC which is $2.4 \%$ of all patients. Previous studies reported a rate between $1 \%$ and $12.5 \%$ of Type I GC $(11,13-15,29-30)$. The wide range of the prevalence rates of Type I GC among several studies could be explained by different settings where patients were selected, such as type of hospital (secondary, tertiary center), symptoms/signs of presentation, type of patient (in-patient, out-patient).

In order to identify patient features associated with the presence of Type I GC, we compared the baseline features between CAG patients with and without Type I GC. Higher levels of gastrin and $\mathrm{CgA}$ were associated with the presence of Type I GC by univariate analysis. A recent review has confirmed that the $\mathrm{CgA}$ is the most sensitive biomarker in neuroendocrine tumors and it is more frequently elevated in well-differentiated tumors compared to poorly differentiated ones (31). However, patients with atrophic gastritis present high values of $\mathrm{CgA}$ (32) and the low specificity of the CgA assay does not identify those with Type I GC among CAG patients as already reported (33). For the same reasons, gastrin does not detect patients with Type I GC as it is increased in all CAG patients. In fact, as shown in Table 2, although patients Type I GC had a median value of gastrin higher than the other CAG patients, the ranges of gastrin overlapped widely between the two groups. We retain that these assays are clinically useful for identifying patients with CAG diagnosis or to exclude those from patients with Type III GC, but they cannot be considered as markers of the presence of Type I GC.

The presence of ECL-dysplasia was associated more frequently with Type I GC. This pattern of ECL-cells is considered to be the true gastric carcinoid precursor lesion and it can represent the sign of a concomitant carcinoid lesion (19). Our previous study showed that this lesion also carries an increased risk for the development of Type I GC during the follow-up (13). Thus, CAG patients with a diagnosis of ECL-cell dysplasia could benefit from a shorter endoscopic 
follow-up to exclude concomitant Type I GC lesions or to identify new lesions in the gastric mucosa.

Another finding of the present study was that the presence of body polyps increases the risk of a Type I GC in CAG patients. Unfortunately, no features of endoscopic appearance of the gastric polyps (size, number, sessile/penduculated presentation) permitted a differential diagnosis between patients with and without Type I GC. In the group of CAG patients without Type I GC, almost three-fourth of all polyps were hyperplastic and the remaining were adenomas. Hyperplastic polyps are very common among all benign epithelial gastric polyps $(42,43)$ and more frequently associated with CAG $(44,45)$. Importantly, some authors have reported an increased risk of neoplastic progression also for this type of lesions. Moreover, CAG has an increased risk of gastric adenocarcinoma $(14,15)$. As a consequence, each polyp found at gastroscopy should be removed and histologically examined.

Different approaches were proposed for the management of Type I GC such as surgery (34), endoscopic polypectomy $(1,4,12)$, somatostatin analogs $(35,36)$ and an endoscopic follow-up without any specific treatment $(37,38)$. We used a conservative management by endoscopic follow-up and performing polipectomy of all visible polypoid lesions. Only one patient, in which the endoscopic approach failed, underwent gastrectomy. This patient had a deeper neoplastic lesion in the gastric wall, extended to muscolaris propria and metastatic involvement of three lymph nodes. Thus, the surgery in this particular case was appropriate. After surgery, imaging procedures (CT-scan and Octreoscan) for the staging did not reveal metastatic involvement of the other organs. The possibility of more invasive lesions among Type I GC is already described in the literature $(39,40)$ and for patients with larger polyps, local surgical tumor resection is recommended (41).

Finally, in our study, the rate of recurrence of the Type I GC during follow-up was almost of 40\%. This high recurrence rate could be explained by Type I GC misdiagnosis during the previous gastroscopy, by bioptic sampling errors or the continuous trophic effect of 
hypergastrinemia on the gastric mucosa. Endoscopic follow-up every 6-12 months, as suggested also by ENETS guidelines, allowed us to identify recurrent lesions or new lesions (incidencecases) when they had a small size and were easily removable by polipectomy without complications (46). This approach was safe, and the $100 \%$ survival of all Type I GC within the study period is in keeping with previous works $(37,40)$.

Our study has some limitations. The first is the high number of CAG patients who dropped-out during the follow-up, almost $27 \%$. We do not know the clinical outcomes of these CAG patients and, as a consequence, the incidence rate could be underestimated. However, we know that this group of patients did not present demographic or baseline clinical features different from the CAG patients who remained in the study and we retain that the main findings of this study remain generally valid.

Moreover, the power of the statistical analysis was limited by the small numbers of casefindings of Type I GC. However, larger number of case-findings could be obtained only performing studies with larger cohorts and longer period of observation.

In conclusion, this cohort study implies that Type I GC is a rare complication in patients with CAG and the presence of body polyps at gastroscopy and ECL-dysplasia at histological evaluation are strongly associated with the presence of Type I GC.

Financial disclosure: None of the authors had potential conflicts of interest in the present work. Grants Supports: This work was supported by grants from the Italian Ministry for University and Research, PRIN, COFIN 2007 and University Sapienza Roma 2007-2009, Italy. Conflict of Interest: None 


\section{REFERENCES:}

1) Burkitt MD, Pritchard DM. Review article: Pathogenesis and management of gastric carcinoid tumours. Aliment Pharmacol Ther. 2006;24(9):1305-20.

2) Rindi G, Bordi C, Rappel S, et al. Gastric carcinoids and neuroendocrine carcinomas: pathogenesis, pathology, and behavior. World J Surg. 1996;20(2):168-72.

3) Rindi G, Luinetti O, Cornaggia M, et al. Three subtypes of gastric argyrophil carcinoid and the gastric neuroendocrine carcinoma: a clinicopathologic study. Gastroenterology 1993;104(4):994-1006.

4) Mulkeen A, Cha C. Gastric carcinoid. Curr Opin Oncol. 2005 Jan;17(1):1-6.

5) Bordi C, D'Adda T, Azzoni C, et al. Pathogenesis of ECL cell tumors in humans. Yale J Biol Med 1998;71(3-4):273-84.

6) Dockray GJ, VarroA, Dimaline R, et al. The gastrins:their production and biological activities. Annu Rev Physiol 2001;63:119-39

7) Creutzfeldt W. The achlorhydria-carcinoid sequence: role of gastrin. Digestion. 1988;39(2):61-79.

8) Bordi C, D'Adda T, Azzoni C, et al. Hypergastrinemia and gastric enterochromaffin-like cells. Am J Surg Pathol. 1995;19 Suppl 1:S8-19.

9) Modlin IM, Lye KD, Kidd M. A 50-year analysis of 562 gastric carcinoids: small tumor or larger problem? Am J Gastroenterol 2004;99(1):23-32.

10) Ellis L, Shale MJ, Coleman MP. Carcinoid Tumors of the Gastrointestinal Tract: Trends in Incidence in England Since 1971. Am J Gastroenterol 2010 Sep7.[Epub ahead of print] 
11) Lehtola J, Karttunen T, Krekelä I, et al. Gastric carcinoids with minimal or no macroscopic lesion in patients with pernicious anemia. Hepatogastroenterology 1985;32(2):72-6.

12) Modlin IM, Lye KD, Kidd M. Carcinoid tumors of the stomach. Surg Oncol. 2003 Aug;12(2):153-72.

13) Annibale B, Azzoni C, Corleto VD, et al. Atrophic body gastritis patients with enterochromaffin-like cell dysplasia are at increased risk for the development of type I gastric carcinoid. Eur J Gastroenterol Hepatol. 2001;13(12):1449-56.

14) Kokkola A, Sjöblom SM, Haapiainen R, et al. The risk of gastric carcinoma and carcinoid tumours in patients with pernicious anaemia. A prospective follow-up study. Scand J Gastroenterol 1998;33(1):88-92.

15) Sjöblom SM, Sipponen P, Miettinen M, et al. Gastroscopic screening for gastric carcinoids and carcinoma in pernicious anemia. Endoscopy 1988;20(2):52-6.

16) Annibale B, Marignani M, Azzoni C, et al. Atrophic body gastritis: distinct features associated with Helicobacter pylori infection. Helicobacter 1997;2(2):57-64.

17) Lahner E, Bordi C, Di Giulio E, et al. Role of Helicobacter pylori serology in atrophic body gastritis after eradication treatment. Aliment Pharmacol Ther 2002;16(3):507-14.

18) Dixon MF, Genta RM, Yardley JH, et al. Classification and grading of gastritis. The updated Sydney System. International Workshop on the Histopathology of Gastritis, Houston 1994. Am J Surg Pathol 1996;20(10):1161-81.

19) Solcia E, Bordi C, Creutzfeldt W, et al. Histopathological classification of nonantral gastric endocrine growths in man. Digestion. 1988;41(4):185-200. 
20) Berna MJ, Annibale B, Marignani M, et al. A prospective study of gastric carcinoids and enterochromaffin-like cell changes in multiple endocrine neoplasia type 1 and Zollinger-Ellison syndrome: identification of risk factors. J Clin Endocrinol Metab 2008;93(5):1582-91.

21) Bordi C, Corleto VD, Azzoni C, et al. The antral mucosa as a new site for endocrine tumors in multiple endocrine neoplasia type 1 and Zollinger-Ellison syndromes. J Clin Endocrinol Metab 2001;86(5):2236-42.

22) Lahner E, Norman GL, Severi C, et al. Reassessment of intrinsic factor and parietal cell autoantibodies in atrophic gastritis with respect to cobalamin deficiency. Am J Gastroenterol 2009;104(8):2071-9.

23) Lahner E, Centanni M, Agnello G, et al. Occurrence and risk factors for autoimmune thyroid disease in patients with atrophic body gastritis. Am J Med 2008;121(2):136-41.

24) Lahner E, Caruana P, D'Ambra G, et al. First endoscopic-histologic follow-up in patients with body-predominant atrophic gastritis: when should it be done? Gastrointest Endosc 2001;53(4):443-8.

25) Modlin IM, Sandor A, Tang LH, et al. A 40-year analysis of 265 gastric carcinoids. Am J Gastroenterol 1997;92(4):633-8.

26) Hodgson N, Koniaris LG, Livingstone AS, et al. Gastric carcinoids: a temporal increase with proton pump introduction. Surg Endosc 2005;19(12):1610-2.

27) Hirota WK, Zuckerman MJ, Adler DG, et al. Standards of Practice Committee, American Society for Gastrointestinal Endoscopy. ASGE guideline: the role of endoscopy in the surveillance of premalignant conditions of the upper GI tract. Gastrointest Endosc 2006;63(4):570-80. 
28) Marignani M, Delle Fave G, Mecarocci S, et al. High prevalence of atrophic body gastritis in patients with unexplained microcytic and macrocytic anemia: a prospective screening study. Am J Gastroenterol 1999;94:766-72.

29) Stockbrügger RW, Menon GG, Beilby JO, et al. Gastroscopic screening in 80 patients with pernicious anaemia. Gut 1983;24(12):1141-7.

30) Borch K, Renvall H, Kullman E, et al. Gastric carcinoid associated with the syndrome of hypergastrinemic atrophic gastritis. A prospective analysis of 11 cases. Am J Surg Pathol 1987;11(6):435-44.

31) Modlin IM, Gustafsson BI, Moss SF, et al. Chromogranin A--biological function and clinical utility in neuro endocrine tumor disease. Ann Surg Oncol 2010;17(9):2427-43.

32) Borch K, Stridsberg M, Burman P, et al. Basal chromogranin A and gastrin concentrations in circulation correlate to endocrine cell proliferation in type-A gastritis. Scand J Gastroenterol 1997;32(3):198-202.

33) Peracchi M, Gebbia C, Basilisco G, et al. Plasma chromogranin A in patients with autoimmune chronic atrophic gastritis, enterochromaffin-like cell lesions and gastric carcinoids. Eur J Endocrinol 2005;152(3):443-8.

34) Dakin GF, Warner RR, Pomp A, et al. Presentation, treatment, and outcome of type 1 gastric carcinoid tumors. J Surg Oncol 2006;93:368-72.

35) Manfredi S, Pagenault M, de Lajarte-Thirouard AS, et al. Type 1 and 2 gastric carcinoid tumors: long-term follow-up of the efficacy of treatment with a slow-release somatostatin analogue. Eur J Gastroenterol Hepatol 2007;19:1021-5. 
36)Grozinsky-Glasberg S, Kaltsas G, Gur C, et al. Long-acting somatostatin analogues are an effective treatment for type 1 gastric carcinoid tumours. Eur J Endocrinol 2008;159:475-82.

37) Hosokawa O, Kaizaki Y, Hattori M, et al. Long-term follow up of patients with multiple gastric carcinoids associated with type A gastritis. Gastric Cancer 2005;8:42-6.

38) Ravizza D, Fiori G, Trovato C, Fazio N, Bonomo G, Luca F, Bodei L, Pelosi G, Tamayo D, Crosta C. Long-term endoscopic and clinical follow-up of untreated type 1 gastric neuroendocrine tumours. Dig Liver Dis 2007;39(6):537-43.

39) Granberg D, Wilander E, Stridsberg M, et al. Clinical symptoms, hormone profiles, treatment, and prognosis in patients with gastric carcinoids. Gut 1998;24:223-8.

40) Borch K, Ahrén B, Ahlman H, et al. Gastric carcinoids: biologic behavior and prognosis after differentiated treatment in relation to type. Ann Surg 2005;242:64-73.

41) Ruszniewski P, Delle Fave G, Cadiot G, et al. Frascati Consensus Conference; European neuroendocrine Tumor Society. Well-differentiated gastric tumors/carcinomas. Neuroendocrinology 2006;84(3):158-64.

42) Carmack SW, Genta RM, Graham DY, et al. Management of gastric polyps: a pathologybased guide for gastroenterologists. Nat Rev Gastroenterol Hepatol 2009;6(6):331-41.

43) Goddard AF, Badreldin R, Pritchard DM, et al. British Society of Gastroenterology. The management of gastric polyps. Gut 2010;59(9):1270-6.

44) Dirschmid K, Platz-Baudin C, Stolte M. Why is the hyperplastic polyp a marker for the precancerous condition of the gastric mucosa? Virchows Arch 2006; 448: 80-84. 
45) Di Giulio E, Lahner E, Micheletti A, et al. Occurrence and risk factors for benign epithelial gastric polyps in atrophic body gastritis on diagnosis and follow-up. Aliment Pharmacol Ther 2005;21(5):567-74.

46) Arnold R, Chen Y, Costa F, at al .ENETS Consensus Guidelines for the Standards of Care in Neuroendocrine Tumors: Follow-Up and Documentation. Neuroendoscrinology 2009; 90:227-233.

\section{LEGEND TO FIGURES}

Figure 1: Study population

Figure 2: Kaplan-Meier Analysis: Intervals between initial diagnosis of atrophic body gastritis and diagnosis of Type I gastric carcinoids. Proportion of patients with atrophic body gastritis who remained free of Type I gastric carcinoids. 
TABLE 1: Baseline features of 15 CAG patients with prevalent and incident Type I GCs.

\begin{tabular}{|c|c|c|c|c|c|c|c|c|c|}
\hline Patients & Gender & $\begin{array}{c}\text { Age } \\
\text { (years) }\end{array}$ & $\begin{array}{l}\text { Gastrin } \\
(\mathrm{pg} / \mathrm{ml})\end{array}$ & $\begin{array}{c}\mathrm{CgA} \\
(\mathbf{n g} / \mathbf{m l})\end{array}$ & $\begin{array}{c}\text { Body } \\
\text { Atrophy } *\end{array}$ & $\begin{array}{l}\text { Pernicious } \\
\text { Anaemia }\end{array}$ & $\begin{array}{l}\text { Endoscopic } \\
\text { Findings }\end{array}$ & $\begin{array}{c}\text { Detection of } \\
\text { Type I GC }\end{array}$ & Recurrence \\
\hline 1 & $\mathrm{~F}$ & 45 & 305 & 60 & 2 & No & $\begin{array}{c}\text { Body polyp of } \\
0.5 \mathrm{~cm}\end{array}$ & At Diagnosis & No \\
\hline 2 & $\mathrm{M}$ & 67 & 975 & 175 & 3 & Yes & $\begin{array}{l}\text { Body polyp of } \\
0.5 \mathrm{~cm}\end{array}$ & At Diagnosis & $\begin{array}{l}\text { At 4-month follow- } \\
\text { up }\end{array}$ \\
\hline 3 & $\mathrm{~F}$ & 40 & 975 & 150 & 3 & No & $\begin{array}{c}\text { Body polyp of } \\
0.6 \mathrm{~cm}\end{array}$ & At Diagnosis & No \\
\hline 4 & $\mathrm{~F}$ & 40 & 570 & 140 & 3 & No & Normal mucosa & At Diagnosis & $\begin{array}{l}\text { At } 6,15,32 \text {-month } \\
\text { follow-up }\end{array}$ \\
\hline 5 & $\mathrm{~F}$ & 66 & 690 & 245 & 3 & No & $\begin{array}{c}\text { Body polyp of } \\
0.5 \mathrm{~cm}\end{array}$ & At Diagnosis & No \\
\hline 6 & $\mathrm{~F}$ & 72 & 680 & 250 & 3 & Yes & $\begin{array}{c}\text { Body polyp of } \\
0.5 \mathrm{~cm}\end{array}$ & At Diagnosis & $\begin{array}{l}\text { At 3,5-month follow- } \\
\text { up }\end{array}$ \\
\hline 7 & $\mathrm{M}$ & 59 & 2000 & 167 & 2 & Yes & $\begin{array}{c}\text { Body polyp of } \\
0.3 \mathrm{~cm}\end{array}$ & At Diagnosis & No \\
\hline 8 & $\bar{F}$ & 61 & 1150 & 150 & 3 & Yes & $\begin{array}{c}\text { Body polyp of } \\
0.5 \mathrm{~cm}\end{array}$ & At Diagnosis & No \\
\hline 9 & M & 55 & 1183 & 547 & 2 & No & $\begin{array}{c}\text { Body polyp of } \\
3 \mathrm{~cm}\end{array}$ & At Diagnosis & $\begin{array}{l}\text { No metastasis after } \\
\text { total gastrctomy }\end{array}$ \\
\hline 10 & $\mathrm{M}$ & 47 & 1090 & 150 & 3 & Yes & Normal mucosa & $\begin{array}{l}\text { At 31-month } \\
\text { follow-up }\end{array}$ & $\begin{array}{l}\text { At 35,46,64-month } \\
\text { follow-up }\end{array}$ \\
\hline 11 & $\mathrm{M}$ & 67 & 500 & 405 & 2 & No & $\begin{array}{l}\text { Body polyp of } \\
0.5 \mathrm{~cm}\end{array}$ & $\begin{array}{l}\text { At 31-month } \\
\text { follow-up }\end{array}$ & No \\
\hline 12 & $\mathrm{M}$ & 69 & 220 & 120 & 3 & No & $\begin{array}{c}\text { Body polyp of } \\
0.5 \mathrm{~cm}\end{array}$ & $\begin{array}{l}\text { At 41-month } \\
\text { follow-up }\end{array}$ & No \\
\hline 13 & $\mathrm{~F}$ & 65 & 2800 & 370 & 3 & No & Normal mucosa & At 7-month & At $13,18,50$-month \\
\hline
\end{tabular}




\section{Page 21 of 24}

Alimentary Pharmacology \& Therapeutic

\begin{tabular}{|l|c|c|c|c|c|c|c|c|c|}
\hline & & & & & & & follow-up & follow-up \\
\hline $\mathbf{1 4}$ & F & 23 & 565 & 230 & 3 & Yes & $\begin{array}{c}\text { Body polyp of } \\
1.2 \mathrm{~cm}\end{array}$ & $\begin{array}{c}\text { At 59-month } \\
\text { follow-up }\end{array}$ \\
\hline $\mathbf{1 5}$ & F & 49 & 1475 & 240 & 3 & Yes & $\begin{array}{c}\text { Body polyp of } \\
0.4 \mathrm{~cm}\end{array}$ & $\begin{array}{c}\text { At 18-month } \\
\text { follow-up }\end{array}$ & $\begin{array}{c}\text { At 30,37,61-month } \\
\text { follow-up }\end{array}$ \\
\hline
\end{tabular}

* scored accordingly to the Sydney System. 
TABLE 2: Baseline clinical, biochemical and histological features of 214 CAG patients with and without Type I GC.

\begin{tabular}{|l|c|c|l|}
\hline & $\begin{array}{c}\text { Type I GC } \\
\mathbf{n = 1 5}\end{array}$ & $\begin{array}{c}\text { CAG } \\
\mathbf{n = 1 9 9}\end{array}$ & \multicolumn{1}{|c|}{$\boldsymbol{p}$} \\
\hline Age, years (range) & $59(23-72)$ & $54(22-77)$ & 0.39 \\
\hline Female gender, $\mathrm{( \% )}$ & $9(60)$ & $137(68.8)$ & 0.7 \\
\hline Gastrin, pg/ml, median (range) & $832.5(220-2800)$ & $500(50-2700)$ & $\mathbf{0 . 0 1}$ \\
\hline Pepsinogen I, ng/ml, median (range) & $10(3-28)$ & $10(3-79)$ & 0.6 \\
\hline Chromogranin A, ng/ml, median (range) & $171(60-405)$ & $100(30-280)$ & $\mathbf{0 . 0 0 0 1}$ \\
\hline Pernicious Anemia, $\mathrm{n}(\%)$ & $7(46.6)$ & $98(49.2)$ & 1 \\
\hline Family history for gastric cancer, $\mathrm{n}(\%)$ & $3(20)$ & $18(9)$ & 0.13 \\
\hline Smoking habit, $\mathrm{n}(\%)$ & $8(53.3)$ & $81(40.7)$ & 0.39 \\
\hline PCA, $\mathrm{n}(\%)$ & $14(93.3)$ & $158(79.3)$ & 0.3 \\
\hline Hpylori positivity, $\mathrm{n}(\%)$ & $7(46.6)$ & $84(42.2)$ & 0.79 \\
\hline Dyspepsia, $\mathrm{n}(\%)$ & $7(46.6)$ & $43(21.6)$ & 0.05 \\
\hline AITD, $\mathrm{n}(\%)$ & $9(60)$ & $91(46)$ & 0.29 \\
\hline ECL-dysplasia*, $\mathrm{n}(\%)$ & $7(46.6)$ & 0 & $<\mathbf{0 . 0 0 0 0 0 1}$ \\
\hline Atrophic pangastritis, $\mathrm{n}(\%)$ & $2(13.3)$ & $44(22.1)$ & 0.5 \\
\hline Body Atrophy, $\mathrm{n}(\%)$ & & $22(11.3)$ & 0.37 \\
$\quad$ Mild & 0 & $55(27.4)$ & 1 \\
\hline $\begin{array}{l}\text { Moderate } \\
\text { Severe }\end{array}$ & $4(26.6)$ & $122(61.3)$ & 0.4 \\
\hline
\end{tabular}

$\mathrm{PCA}=$ parietal cell antibodies; $\mathrm{CAG}=$ chronic atrophic gastritis; $\mathrm{AITD}=$ autoimmune thyroid disease

*ECL-dysplasia was concurrent at Type I GC in 5 prevalent and 2 incident cases.

Data are expressed as median(range). Mann-Whitney test or Fisher-test were used for the comparison of baseline

features between two groups 
TABLE 3: Comparison of gastric polyps in CAG patients with and without Type I GC.

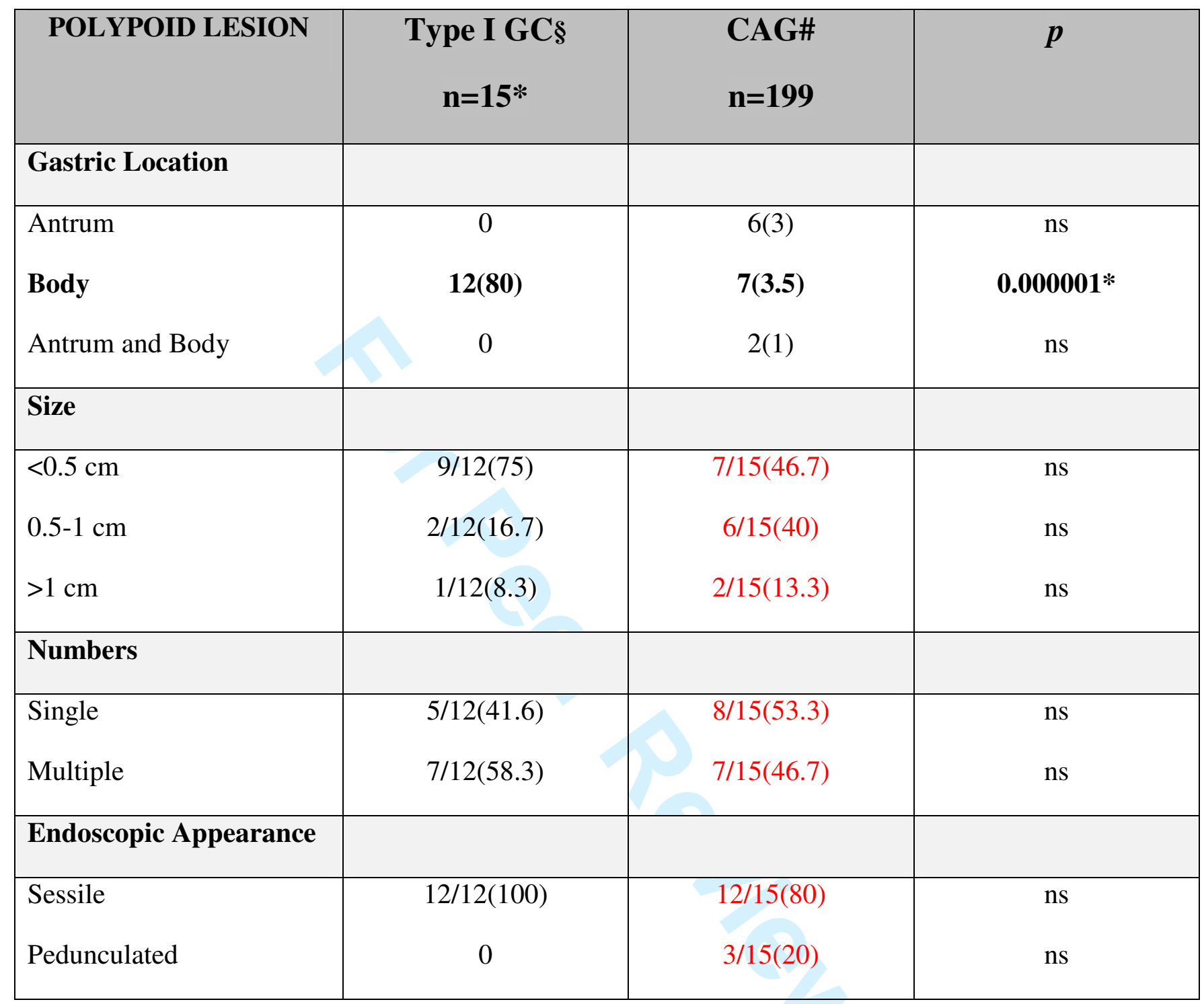

$\S$ reported polypoid lesions refer to gastroscopy performed at the moment of type I GC diagnosis; \# reported polypoid lesions refer to baseline gastroscopy; *3patients had intramucosal carcinoids;

Data are expressed as proportions and Fisher-test was used for the comparison between the two groups. 
$\boldsymbol{n}=\mathbf{3 6 7}$ patients with atrophic body gastritis referred to the Department of Digestive and Liver Diseases between January 1992 and June 2008
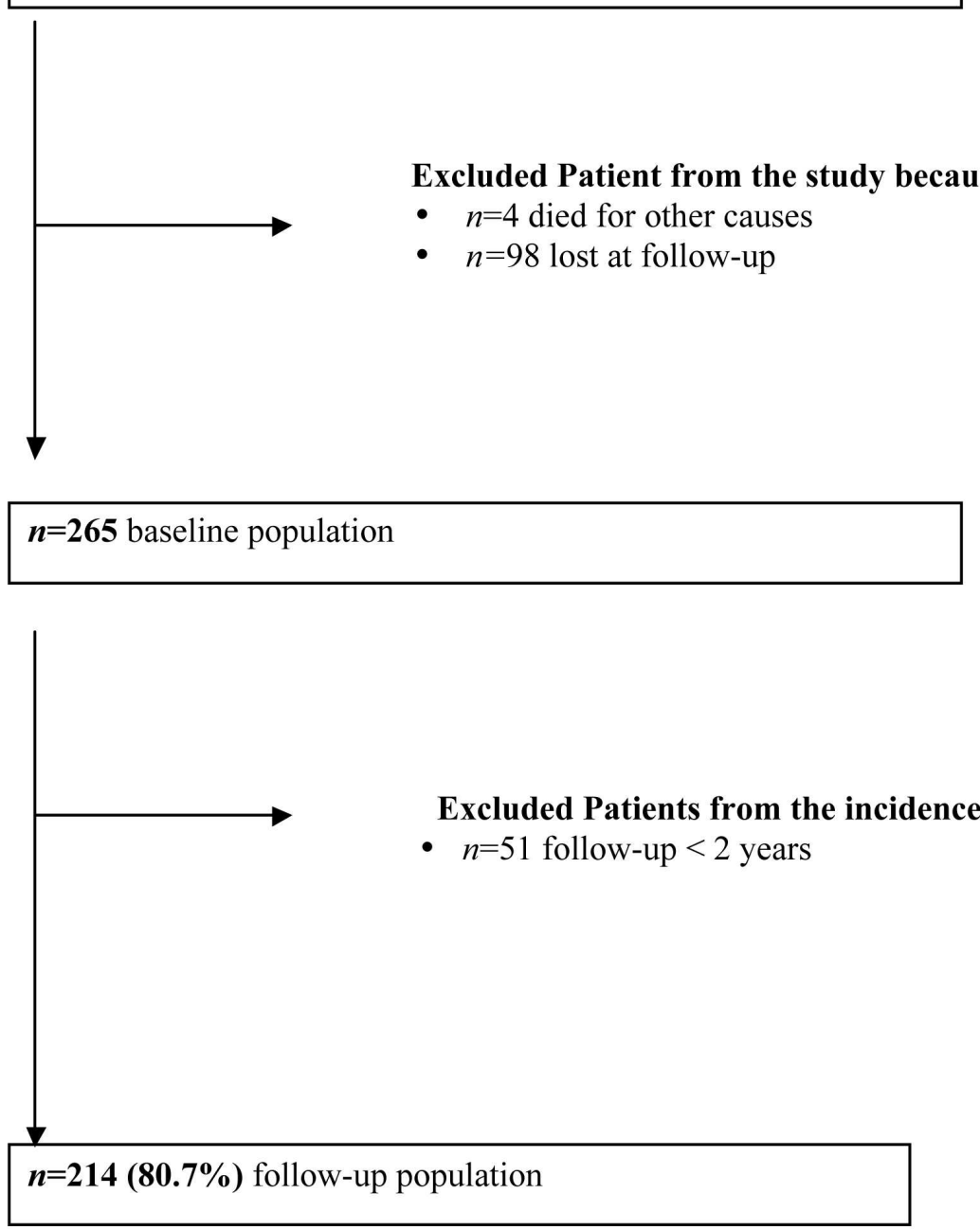

$120 \times 147 \mathrm{~mm}(400 \times 400 \mathrm{DPI})$ 